Article

\title{
Oxygen Content-Controllable Synthesis of Non-Stoichiometric Silicon Suboxide Nanoparticles by Electrochemical Anodization
}

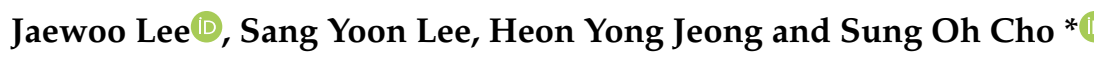 \\ Department of Nuclear and Quantum Engineering, Korea Advanced Institute of Science and \\ Technology (KAIST), Daejeon 34141, Korea; jw.lee@kaist.ac.kr (J.L.); sangyoonlee@kaist.ac.kr (S.Y.L.); \\ jeong93@kaist.ac.kr (H.Y.J.) \\ * Correspondence: socho@kaist.ac.kr; Tel.: +82-(0)42-350-3823; Fax: +82-(0)42-350-3810
}

Received: 8 October 2020; Accepted: 23 October 2020; Published: 27 October 2020

\begin{abstract}
A facile route to producing non-stoichiometric silicon suboxide nanoparticles $\left(\mathrm{SiO}_{\mathrm{x}} \mathrm{NPs}_{\text {, }}\right.$ $0<x<1$ ) with an adjustable oxygen content is proposed. The process is based on electrochemical anodization involving the application of a strong electric field near the surface of a Si electrode to directly convert the $\mathrm{Si}$ electrode into $\mathrm{SiO}_{x} \mathrm{NPs}$. The difference in ion mobility between oxygen species $\left(\mathrm{O}^{2-}\right.$ and $\left.\mathrm{OH}^{-}\right)$, formed during anodization, causes the production of non-stoichiometric $\mathrm{SiO}_{\mathrm{x}}$ on the surface of the Si while, simultaneously, fluoride ions in the electrolyte solution etch the formed $\mathrm{SiO}_{\mathrm{x}}$ layer, generating NPs under the intense electric field. The adjustment of the applied voltage and anodization temperature alters the oxygen content and the size of the $\mathrm{SiO}_{\mathrm{x}} \mathrm{NPs}$, respectively, allowing the characteristics of the NPs to be readily controlled. The proposed approach can be applied for mass production of $\mathrm{SiO}_{\mathbf{x}} \mathrm{NPs}$ and is highly promising in the field of batteries and optoelectronics.
\end{abstract}

Keywords: nanoparticle; silicon suboxide; anodization; oxygen content

\section{Introduction}

Nanoparticles are highly valuable for an extensive range of applications due to their high specific surface area. Silicon suboxide nanoparticles $\left(\mathrm{SiO}_{\mathrm{x}} \mathrm{NPs}, 0<\mathrm{x}<1\right)$, in particular, exhibit unique electrical, optical, chemical, and mechanical properties, allowing the particles to be actively used as semiconductors and a coating material [1-3]. The properties of $\mathrm{SiO}_{\mathbf{x}} \mathrm{NPs}$ are heavily dependent on the oxidation state of the Si [4-6], which determines the oxygen content of the NPs.

$\mathrm{SiO}_{\mathrm{x}}$ NPs are being studied largely for their application as the anode material in lithium-ion batteries to potentially meet the high demand for batteries with higher capacity and longer service life [1,4,7-9]. Currently, the batteries are reported to have a high charge capacity [2,10-12] and a low volume expansion ratio [8,13]. Lithium oxides (e.g., $\mathrm{Li}_{2} \mathrm{O}$ and $\mathrm{Li}_{4} \mathrm{SiO}_{4}$ ), produced by $\mathrm{Li}$ ion insertion into $\mathrm{SiO}_{x}$ during initial charging, serve to buffer volume changes, improving charge cycle performance $[14,15]$. It has been previously reported that the charge capacity and coulombic efficiency increase while the cyclability of the batteries decreases as the oxygen content of SiO $\mathrm{NPS}_{\mathbf{S}}$ decreases $[4,8,10,13]$. Therefore, the optimal oxygen content of $\mathrm{SiO}_{\mathrm{x}} \mathrm{NPs}$ must be considered in order to produce efficient lithium-ion batteries.

$\mathrm{SiO}_{\mathrm{x}} \mathrm{NPs}$ are also commonly applied as anti-reflective coating due to their attractive optical properties [16,17]. Many studies have found that the refractive index of $\mathrm{SiO}_{\mathrm{x}}$ decreases as the oxygen content increases $[3,18]$. Therefore, being able to alter the oxygen content of $\mathrm{SiO}_{\mathrm{x}} \mathrm{NPs}$ allows the refractive index of the NPs to be controllable and, with adjustable refractive index, applications of $\mathrm{SiO}_{\mathrm{x}}$ NPs are diverse in the field of optics. Furthermore, the anti-reflectivity of $\mathrm{SiO}_{\mathrm{x}} \mathrm{NPs}$ is not limited to a particular wavelength; the NPs can improve the photovoltaic efficiency at various wavelengths $[6,19]$. 
The excellent passivating property of $\mathrm{SiO}_{x}$ NPs also makes the NPs suitable for incorporation into organic light-emitting diodes $[3,6,20]$. $\mathrm{SiO}_{x} \mathrm{NPs}$ are chemically and mechanically stable in general, but by adjusting the oxygen content of the NPs, the reactivity of the NPs can be increased. In addition, $\mathrm{SiO}_{x} \mathrm{NPs}$ have abundant oxygen vacancies, allowing the NPs to be potentially utilized as a sensing material [21-23]. Oxygen vacancies become more prevalent and electrical conductivity increases as the oxygen content of $\mathrm{SiO}_{\mathrm{x}}$ NPs decreases [24,25]. Both the passivating and insulating properties of $\mathrm{SiO}_{\mathrm{x}}$ play an important role in determining the sensitivity and selectivity of gas sensing, thus, synthesizing $\mathrm{SiO}_{x} \mathrm{NPs}$ with adjustable oxygen content is highly important.

$\mathrm{Si}$ is not very reactive at low temperatures; therefore, conventional $\mathrm{SiO}_{\mathrm{x}} \mathrm{NPs}$ synthesis procedures involve high-temperature reactions. The high-temperature reactions can be classified into two categories: melting-condensation [9] and chemical vapor deposition [1,2,4]. In the former, $\mathrm{Si}$ (or $\mathrm{Si}$ mixed with silica) is melted and oxygen is injected. The formed molten $\mathrm{SiO}_{\mathrm{x}}$ is then evaporated, after which, the vaporized $\mathrm{SiO}_{\mathrm{x}}$ is condensed rapidly and extracted in the form of NPs. In the chemical vapor deposition reaction, microwave is used to induce the plasma state of Si-based precursors, allowing oxygen to be deposited into $\mathrm{Si}$. Non-stoichiometric $\mathrm{SiO}_{\mathrm{x}}$ is created by altering the pressure and the amount of oxygen present during the reaction, and the volatile molecules are extracted as NPs. Nonetheless, both approaches have difficulties fabricating $\mathrm{SiO}_{x}$ particles smaller than $200 \mathrm{~nm}$, are highly time-consuming, and require complicated setups for housing high-temperature systems.

In this paper, we propose the use of anodization, an electrochemical process, to synthesize $\mathrm{SiO}_{\mathrm{x}} \mathrm{NPs}$ with adjustable oxygen content. Anodization is typically employed to fabricate a uniform nanostructured (nanotubular or nanoporous) oxide layer on metallic surfaces [26-29]. The two key reactions required to form nanostructures are oxidation and etching. When a metal surface is oxidized, etching agents in the electrolyte react with the oxide layer to form nanostructures. A recent study reported that metal oxide NPs can be directly obtained from anodizing metal wires [30]. However, to the best of our knowledge, there have been no attempts to synthesize oxide NPs from anodizing poorly conductive metalloids like $\mathrm{Si}$. In addition, unlike the previously synthesized metal-based NPs (e.g., $\mathrm{Al}_{2} \mathrm{O}_{3}, \mathrm{TiO}_{2}, \mathrm{ZrO}_{2}$, etc.), the $\mathrm{SiO}_{\mathrm{x}} \mathrm{NPs}$ synthesized in this work are non-stoichiometric. The anodization process provides multiple advantages, such as immediacy, simplicity, capability to synthesize at low temperatures, and economic efficiency, over the conventional procedures. In this study, we have successfully synthesized $\mathrm{SiO}_{x} \mathrm{NPs}$ with adjustable oxygen content and size, and the NPs will have significant applications in the fields of batteries and optoelectronics.

\section{Materials and Methods}

\subsection{Materials}

Doped $\mathrm{Si}$ is conductive enough to allow for anodization. P-type $\mathrm{Si}$ is generally used, but n-type Si can also be employed under specific illumination conditions [31,32]. To simplify the experimental process, boron-doped p-type Si wafers $(<100>$ ) with a resistance of $0.001-0.003 \Omega \mathrm{cm}$ (Tasco, Miami, FL, USA) were used in this work. In order to generate a very intense electric field adjacent to $\mathrm{Si}$, the wafers were cut into $1.0 \mathrm{~mm} \times 0.5 \mathrm{~mm}$ thin rods with a high aspect ratio by arc discharging in water. Halogen elements are generally used as etching agents, thus, in this study, fluorine anions from reagent-grade ammonium fluoride $\left(\mathrm{NH}_{4} \mathrm{~F}\right)$ (Sigma-Aldrich, St. Louis, MO, USA) were chosen. The electrolyte solution was prepared with deionized (DI) water.

\section{2. $\mathrm{SiO}_{x} \mathrm{NPs}$ Preparation}

Prior to anodization, Si rods were sonicated in acetone and ethanol for $5 \mathrm{~min}$ each, followed by rinsing with DI water to remove any impurities present on the surfaces of the rods. The rods were then dried under a nitrogen stream and no further treatments were performed on the rods. Anodization was performed in $10 \mathrm{M} \mathrm{NH}_{4} \mathrm{~F}$ aqueous solution with a typical two-electrode setup employing a $\mathrm{Si}$ rod as the anode and a platinum sheet $(10 \mathrm{~mm} \times 40 \mathrm{~mm} \times 0.5 \mathrm{~mm})$ as the cathode (Figure 1a). The two electrodes 
were placed $10 \mathrm{~mm}$ apart and a voltage was applied with a $900 \mathrm{~W}$ DC power supply (OPS-3003, ODA Technologies, Incheon, Korea). The anodization process was carried out at a temperature that was kept constant using a thermostatic bath (RW-3040G, Lab. Companion, Daejeon, Korea) and was maintained for $1 \mathrm{~h}$. During anodization, NPs could be observed precipitating. After anodization, the NPs were extracted by vacuum filtration. The NPs were then rinsed thoroughly with DI water and dried in a desiccator at room temperature under vacuum.
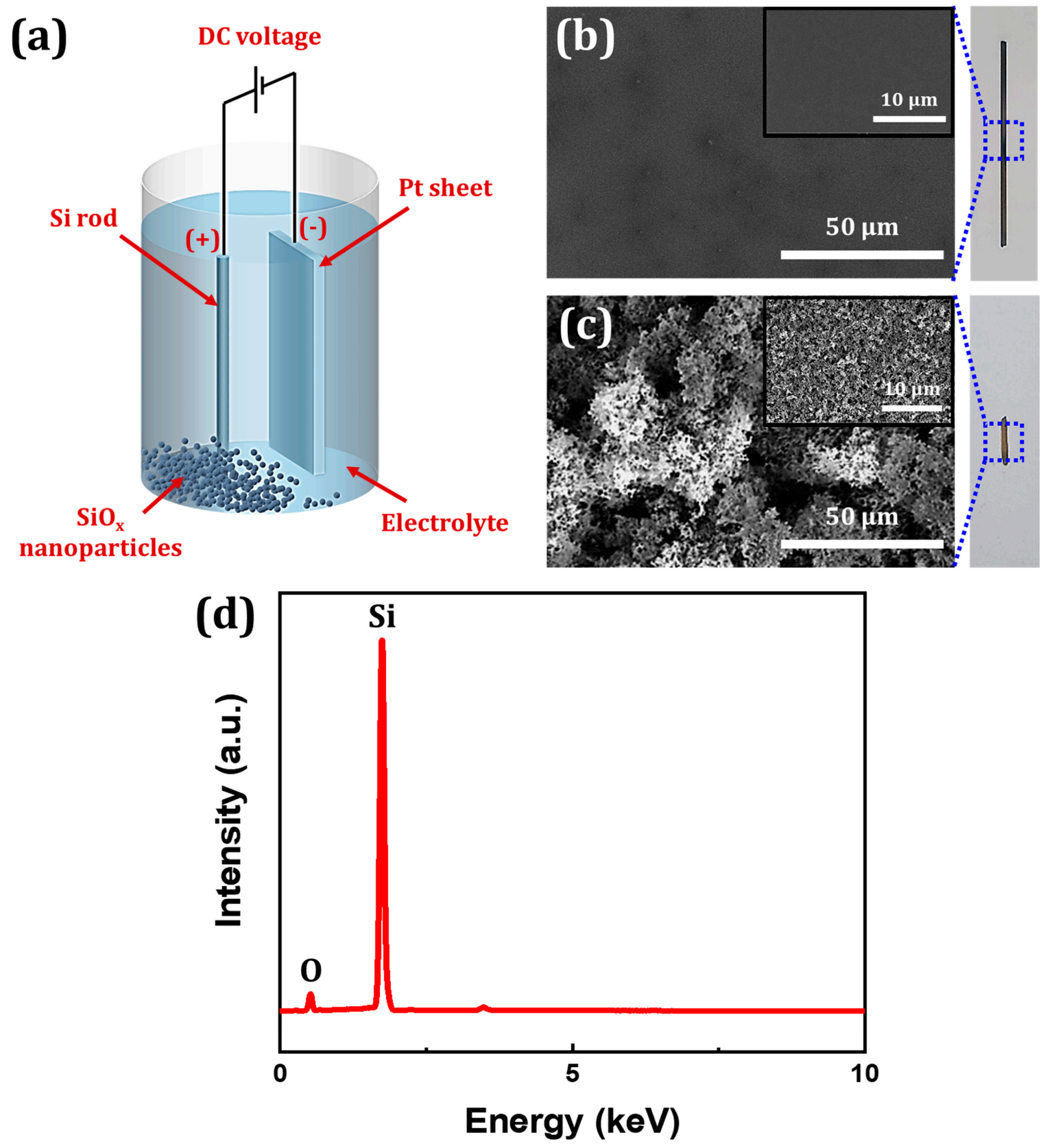

Figure 1. (a) An illustration showing the two-electrode anodization process for $\mathrm{SiO}_{\mathrm{x}}$ nanoparticle (NP) synthesis. FESEM images of a Si rod surface (b) before and (c) after anodization (digital images shown on the right). (d) EDX spectrum of the Si rod surface after anodization at a constant voltage and temperature of $7.5 \mathrm{~V}$ and $10^{\circ} \mathrm{C}$, respectively. 


\subsection{Characterization}

The synthesized NPs and the surface morphology of a Si rod before and after anodization were characterized using a field emission scanning electron microscope (FESEM, Magellan400, FEI, Hillsboro, OR, USA). The size of the NPs was determined from FESEM images collectively containing at least 100 particles utilizing the ImageJ software (Laboratory for Optical and Computational Instrumentation, University of Wisconsin-Madison, Madison, WI, USA) [33]. The elemental composition of the anodized Si rod surface was deduced using an energy-dispersive X-ray spectrometer (EDX) equipped with the FESEM. Further investigation into the morphology and crystallinity of the NPs were carried out with a transmission electron microscope (TEM, Titan cubed G2 60-300, FEI, Hillsboro, OR, USA). Chemical bonds present in the NPs were analyzed with an X-ray photoelectron spectrometer (XPS, K-alpha, Thermo VG Scientific, Waltham, MA, USA) for Al K $\alpha$ radiation $(1486.7 \mathrm{eV})$.

\section{Results and Discussion}

\subsection{Synthesis of Silicon Oxide NPs}

Electrochemical anodization was performed on a Si rod at a constant voltage and temperature of $7.5 \mathrm{~V}$ and $10^{\circ} \mathrm{C}$, respectively. After completion of the process, the surface of the Si rod was examined for any changes. It was visibly noticeable that the rod became shorter and lost its luster due to etching and oxidation, respectively (digital photographs shown beside Figure $1 b, c)$. Figure $1 b, c$ shows FESEM images of the surface of the Si rod before and after anodization. The initially smooth surface of the rod became highly rough after anodization. EDX spectrum, shown in Figure 1d, confirms that the roughness indeed arises from the silicon oxide layer that has formed on the surface of the rod. The anodization experiment was then repeated, but at different voltages of 7.5, 10.0, and $12.5 \mathrm{~V}$. The temperature at which the process was carried out was also set to $5{ }^{\circ} \mathrm{C}$ to mitigate the local heat buildup resulting from the high electrical resistance of Si. In all cases, precipitation was observed; Figure 2a shows that the formed precipitate consists of individual particles with a size of less than $100 \mathrm{~nm}$. The intense electric field near the Si surface allows the silicon oxide layer to be extracted as NPs. The obtained FESEM image was adjusted to have high contrast for size distribution analysis. Each particle was assumed to be spherical and the diameter of each particle was calculated using ImageJ. From the high contrast image, as shown in Figure S1, it was determined that the NPs were approximately 41.4, 62.2 , and $71.8 \mathrm{~nm}$ in diameter with only a slight variance when synthesized at constant voltages of $7.5,10.0$, and $12.5 \mathrm{~V}$, respectively (Figure $2 \mathrm{~d}$ ). A possible explanation for this phenomenon is that the local electrolyte temperature changes as the applied voltage varies due to Joule heating becoming more prevalent as the voltage rises. Investigation into the crystallinity of particles suggests that the particles have no specific crystallographic orientation as shown in the high-resolution TEM image (Figure 2b). The selected area electron diffraction (SAED) pattern, shown in the inset of Figure $2 b$, further confirms that the particles are amorphous. The XPS measurement of the synthesized particles was collected to identify the elements present; prominent Si and O peaks can be observed in the XPS spectrum (Figure $2 \mathrm{c}$ ). The $\mathrm{wt} \%$ of $\mathrm{Si}$ and $\mathrm{O}$ vary slightly with the applied voltage (Table S1). The result supports that the particles are $\mathrm{SiO}_{\mathrm{x}}$. The observable carbon peaks near $285 \mathrm{eV}$ can be attributed to the membrane filter utilized to extract the particles and the copper tape used during the XPS measurement, and the sharp peak near $150 \mathrm{eV}$ can be attributed to plasmons [34]. No peaks corresponding to the presence of nitrogen and fluorine, two elements found in the electrolyte, can be observed. From these results, it can be concluded that $\mathrm{SiO}_{\mathrm{x}} \mathrm{NPs}$ can be directly synthesized via anodization. 

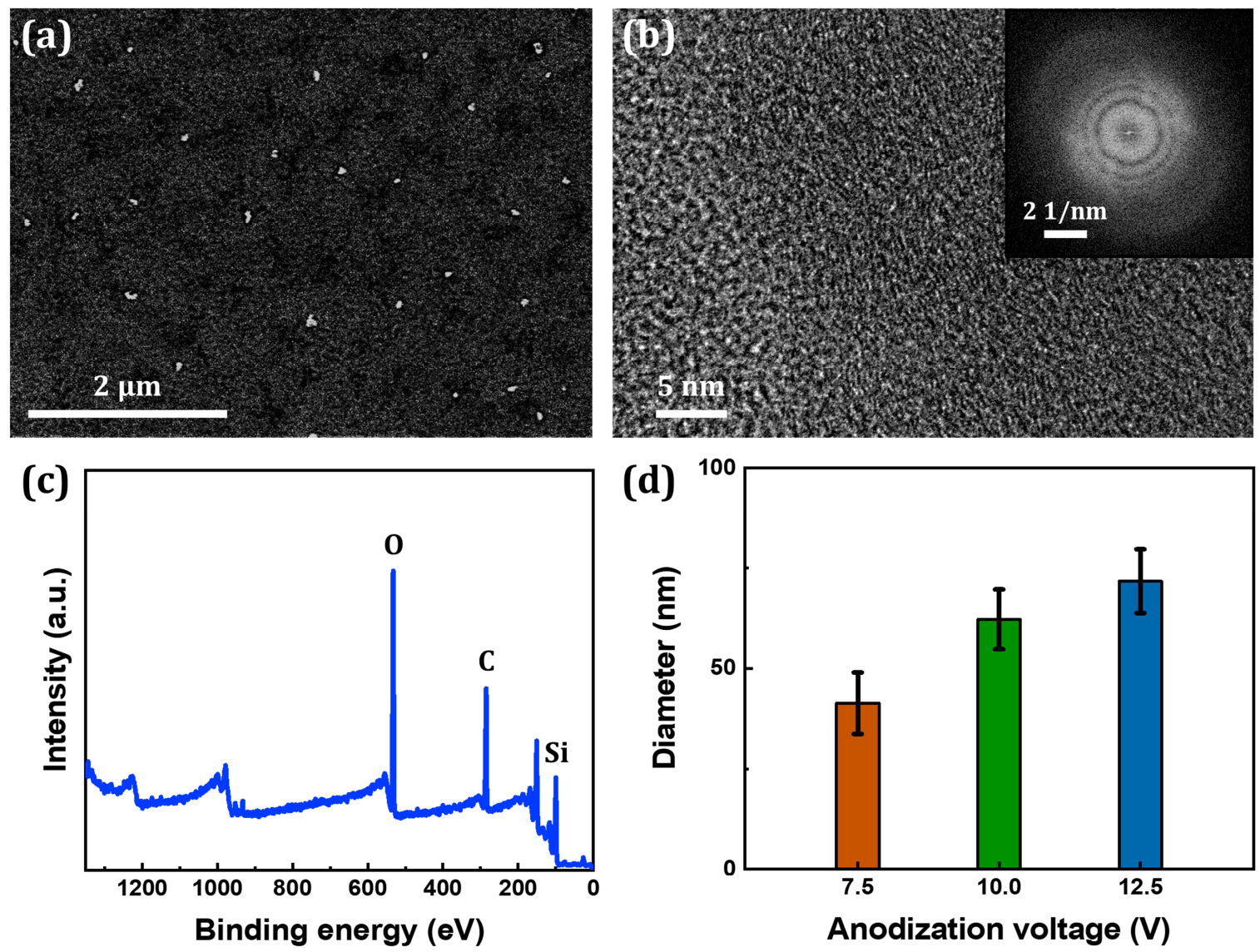

Figure 2. (a) FESEM image, (b) high-resolution TEM image (inset: SAED pattern), and (c) XPS survey spectrum of $\mathrm{SiO}_{\mathrm{x}} \mathrm{NPs}$ synthesized at a temperature of $5{ }^{\circ} \mathrm{C}$ and a constant voltage of $10.0 \mathrm{~V}$. (d) Average particle size of synthesized $\mathrm{SiO}_{\mathbf{x}} \mathrm{NPs}$ as a function of anodization voltage.

\subsection{Control of Oxygen Content in $\mathrm{SiO}_{x} \mathrm{NPS}$}

The oxygen content of $\mathrm{SiO}_{x}$ can be described as the average oxidation number of $\mathrm{Si}$. The oxidation number is expressed as the $\mathrm{x}$-value in " $\mathrm{SiO}_{\mathrm{x}}$ ". The $\mathrm{x}$-value has a significant effect on the properties of $\mathrm{SiO}_{\mathrm{x}}$. In $\mathrm{Si}$, the $\mathrm{Si}$ atoms are arranged in tetragonal formations with four atoms surrounding an atom. When $\mathrm{Si}$ is oxidized, the four surrounding atoms are replaced with $\mathrm{O}$ atoms. The number of replacements that occur determines the oxidation number of $\mathrm{Si}$, and this number can range from 0 to 4 ; the possible resulting states are $\mathrm{Si}-\left(\mathrm{Si}_{4}\right), \mathrm{Si}-\left(\mathrm{Si}_{3} \mathrm{O}\right), \mathrm{Si}-\left(\mathrm{Si}_{2} \mathrm{O}_{2}\right), \mathrm{Si}-\left(\mathrm{SiO}_{3}\right)$, and $\mathrm{Si}-\left(\mathrm{O}_{4}\right)$. The binding energy varies slightly for each oxidation state. According to the random-bonding model, $\mathrm{SiO}_{\mathrm{x}}$ is a combination of the five states and is amorphous. In this connected $\mathrm{SiO}_{\mathrm{x}}$ state, $\mathrm{Si}-\left(\mathrm{Si}_{3} \mathrm{O}\right), \mathrm{Si}^{-}\left(\mathrm{Si}_{2} \mathrm{O}_{2}\right)$, $\mathrm{Si}-\left(\mathrm{SiO}_{3}\right)$, and $\mathrm{Si}-\left(\mathrm{O}_{4}\right)$ can be expressed as $\mathrm{Si}_{2} \mathrm{O}, \mathrm{SiO}, \mathrm{Si}_{2} \mathrm{O}_{3}$, and $\mathrm{SiO}_{2}$, respectively. The frequency distribution of the five oxidation states determines the oxidation number, meaning that the $\mathrm{x}$-value can be adjusted by carefully controlling the production of each oxidation state. Through Si $2 p$ scanning, the $x$-value can be determined employing the equation given in Equation (1).

$$
x=\frac{0.0 \times a+0.5 \times b+1.0 \times c+1.5 \times d+2.0 \times e}{a+b+c+d+e},
$$

where $a, b, c, d$, and $e$ are the peak areas of $\mathrm{Si}^{0}, \mathrm{Si}^{1+}, \mathrm{Si}^{2+}, \mathrm{Si}^{3+}$, and $\mathrm{Si}^{4+}$ peaks, respectively. There are two distinguishable $\mathrm{Si}^{0}$ peaks resulting from spin-orbital splitting into $\mathrm{Si} 2 \mathrm{p}_{1 / 2}$ and $\mathrm{Si} 2 \mathrm{p}_{3 / 2}$; the peak ratio between these two peaks is approximately 1:2, respectively [34]. Table 1 provides Si $2 p$ peak information for each oxidation state. The binding energy of each peak varies slightly with the $x$-value, but the variance is insignificant [35]. 
Table 1. Si 2p peak information for different oxidation states (0 to 4$)$.

\begin{tabular}{|c|c|c|}
\hline Oxidation State & Group & Binding Energy $(\mathrm{eV})[34,36-38]$ \\
\hline $\mathrm{Si}^{0}$ & $\mathrm{Si}$ & $98.9\left(\mathrm{Si} 2 \mathrm{p}_{3 / 2}\right)$ and $99.5\left(\mathrm{Si} 2 \mathrm{p}_{1 / 2}\right)$ \\
\hline $\mathrm{Si}^{1+}$ & $\mathrm{Si}_{2} \mathrm{O}$ & 100.0 \\
\hline $\mathrm{Si}^{2+}$ & $\mathrm{SiO}$ & 101.0 \\
\hline $\mathrm{Si}^{3+}$ & $\mathrm{Si}_{2} \mathrm{O}_{3}$ & 102.1 \\
\hline $\mathrm{Si}^{4+}$ & $\mathrm{SiO}_{2}$ & 103.2 \\
\hline
\end{tabular}

Si 2p spectra, shown in Figure 3, visualizes the chemical-bond distributions of $\mathrm{SiO}_{x} \mathrm{NPs}_{\mathrm{s}}$ synthesized at different anodization voltages. All spectra were referred to the $\mathrm{C} 1 \mathrm{~s}$ line $(285 \mathrm{eV})$. Six peaks can be found in each spectrum with the highest peaks located near 99 and $103 \mathrm{eV}$, the former of which corresponds to the amalgamation of $S i 2 p_{1 / 2}$ and $S i 2 p_{3 / 2}$ peaks. The presence of these two prominent peaks are attributed to $\mathrm{Si}-\mathrm{Si}$ bonding and $\mathrm{O}-\mathrm{Si}-\mathrm{O}$ bonding. Much less noticeable peaks can be found near 100, 101, and $102 \mathrm{eV}$, indicating relatively little formation of $\mathrm{Si}_{2} \mathrm{O}, \mathrm{SiO}$, and $\mathrm{Si}_{2} \mathrm{O}_{3}$. Thus, the result supports that the most frequent oxidation state present in the NPs is the $+4\left(\mathrm{SiO}_{2}\right)$ state, excluding the zero-oxidation state. This uneven formation of oxidation states can be explained as $\mathrm{SiO}_{2}$ being the most stable oxidation state. Furthermore, as anodization voltage increases, $\mathrm{SiO}_{2}$ peak becomes even more dominant. The $\mathrm{x}$-values of $\mathrm{SiO}_{\mathrm{x}}$ synthesized at voltages of 7.5, 10.0, and $12.5 \mathrm{~V}$ were calculated to be $0.42 \pm 0.05,0.64 \pm 0.09$, and $0.89 \pm 0.09$, respectively, indicating that the oxygen content of $\mathrm{SiO}_{\mathrm{x}} \mathrm{NPs}$ increases with rising anodization voltage.

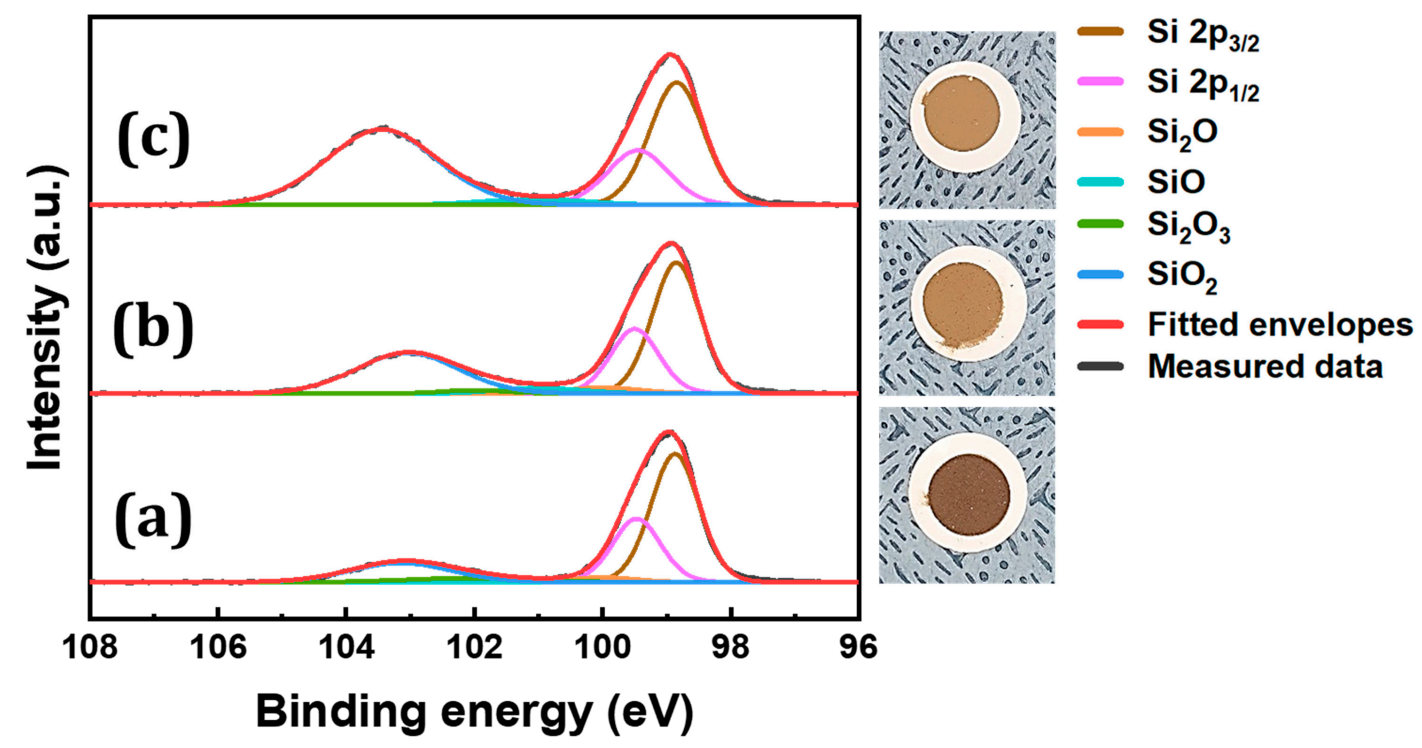

Figure 3. XPS spectra and digital photographs of $\mathrm{SiO}_{\mathrm{x}} \mathrm{NPs}$ synthesized at voltages of $(\mathbf{a}) 7.5 \mathrm{~V},(\mathbf{b}) 10.0 \mathrm{~V}$, and (c) $12.5 \mathrm{~V}$ at a constant temperature of $5^{\circ} \mathrm{C}$.

The mechanism behind the oxygen content change resulting from anodization voltage adjustment is visualized in Figure 4. During anodization, anions of oxygen species $\left(\mathrm{O}^{2-}\right.$ and $\left.\mathrm{OH}^{-}\right)$are created by field-assisted deprotonation of water $[26,39,40]$. It is generally accepted that ion mobility greatly affects the oxidation process during anodization [41,42]. Ion mobility, in a solution, is directly proportional to the charge of the ion and inversely proportional to the mass of the ion. Thus, $\mathrm{O}^{2-}$ ions are transported much more quickly than $\mathrm{OH}^{-}$under a constant electric field. This difference in mobility between the two anions leads to the observed variations in oxygen content of $\mathrm{SiO}_{\mathrm{x}}$. As depicted in Figure 4a, at a low voltage, the low electric field produces little $\mathrm{O}^{2-}$, while also allowing the formed anions to recombine with $\mathrm{H}_{3} \mathrm{O}^{+}$. In addition, there is not a significant difference in mobility between the two aforementioned anions under low electric field. These two factors permit $\mathrm{OH}^{-}$to readily bond with 
Si without having to compete with $\mathrm{O}^{2-}$, leading to the formation of $\mathrm{Si}-\mathrm{OH}$ bonds, which are very soluble in the aqueous solution. Figure $4 \mathrm{~b}$ shows that as the voltage rises, the electric field increases, producing more anions and increasing the mobility difference between $\mathrm{O}^{2-}$ and $\mathrm{OH}^{-}$. With the higher mobility, $\mathrm{O}^{2-}$ outcompetes $\mathrm{OH}^{-}$and $\mathrm{O}-\mathrm{Si}-\mathrm{O}$ bonds become more dominant $\left(\mathrm{SiO}_{2}\right.$ in Figure $\left.3 \mathrm{c}\right)$.
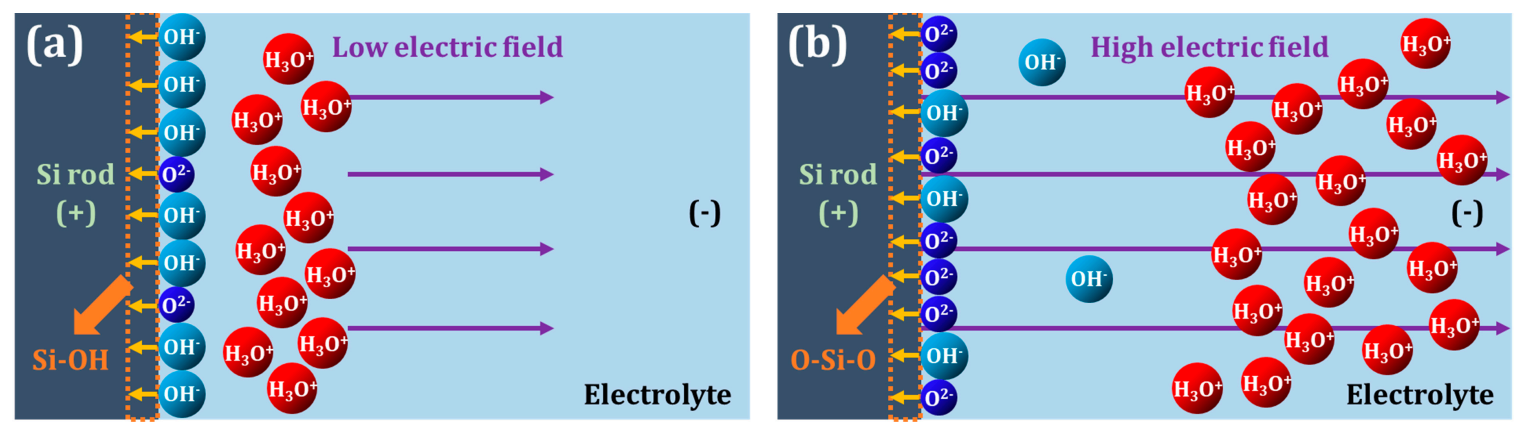

Figure 4. Illustrations of how oxygen content is affected by the anodization voltage ((a) low voltage and (b) high voltage).

\subsection{Size Control of $\mathrm{SiO}_{x} \mathrm{NPs}$}

When $\mathrm{SiO}_{\mathrm{x}} \mathrm{NPs}$ were synthesized at a voltage and temperature of $7.5 \mathrm{~V}$ and $5{ }^{\circ} \mathrm{C}$, respectively, the particles were on average $41.4 \mathrm{~nm}$ in diameter. Fabrication at higher temperatures increases the size of the synthesized NPs as shown in Figure 5; when fabricated at the temperatures of 25, 45, and $65{ }^{\circ} \mathrm{C}$, the average sizes of the synthesized NPs were 99.2, 147.0, and $192.3 \mathrm{~nm}$, respectively. Additionally, more spherical NPs were observed as the fabrication temperature rose. The $x$-value, however, was generally unaffected by the temperature.
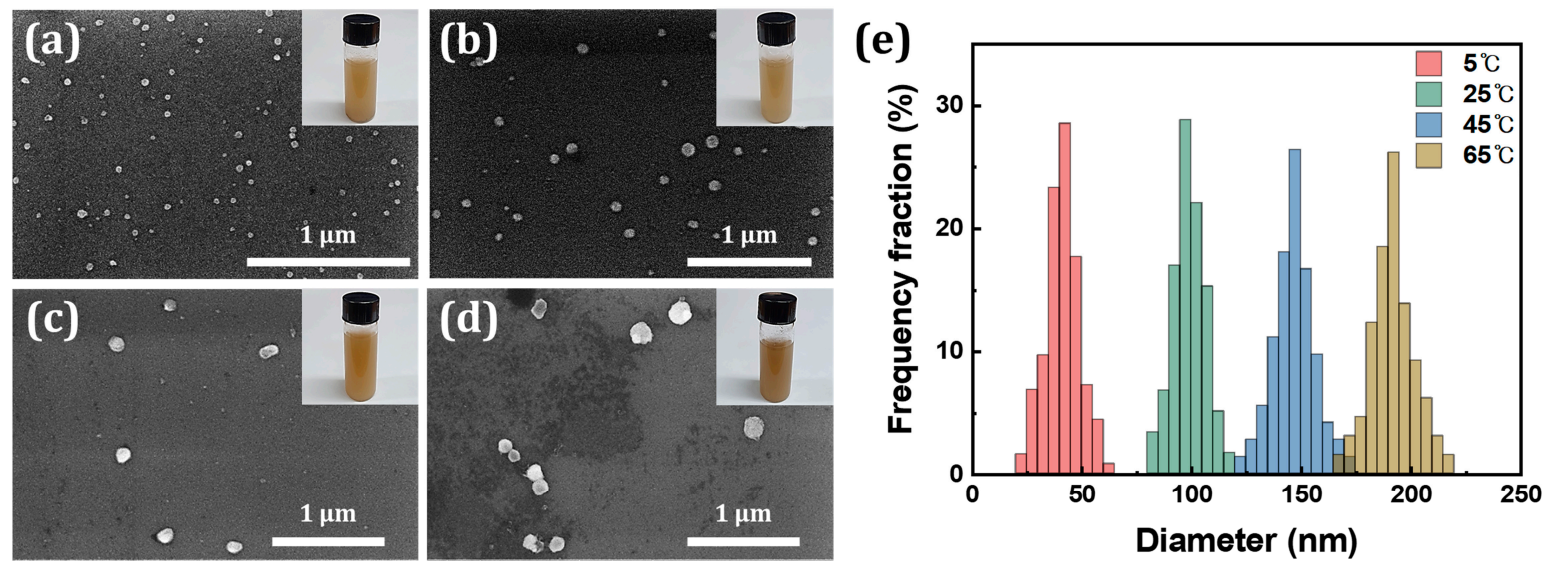

Figure 5. FESEM images of NPs synthesized at temperatures of $(\mathbf{a}) 5^{\circ} \mathrm{C},(\mathbf{b}) 25^{\circ} \mathrm{C},(\mathbf{c}) 45^{\circ} \mathrm{C}$, and (d) $65^{\circ} \mathrm{C}$ at a constant voltage of $7.5 \mathrm{~V}$ (insets: digital photographs of synthesized $\mathrm{SiO}_{\mathrm{x}} \mathrm{NPs}$ dispersed in DI water). (e) The size distributions of synthesized NPs.

Anodization temperature is typically one of the most important factors regarding the morphology of the synthesized oxides. When anodization occurs at a high temperature, the aqueous electrolyte solution has a low viscosity, allowing a high diffusion of $\mathrm{F}^{-}$, an etching agent [43]. Consequently, a high etching rate leads to a high oxidation rate $[28,43]$, ultimately resulting in a production of large particles. Thus, through the adjustment of the anodization temperature, the size of the synthesized $\mathrm{SiO}_{\mathrm{x}}$ NPs can be controlled. 


\section{Conclusions}

Controlling the oxygen content of $\mathrm{SiO}_{x}$ NPs allows the NPs to exhibit diverse properties. We successfully synthesized non-stoichiometric $\mathrm{SiO}_{x} \mathrm{NPs}$ by anodizing a doped $\mathrm{Si}$ rod in an aqueous electrolyte solution. A silicon oxide layer formed on the surface of the rod after anodization, indicating that oxidation and etching took place, and the electric field induced near the surface led to the production of NPs. Raising the applied voltage increased the oxygen content of the synthesized $\mathrm{SiO}_{\mathrm{x}}$ NPs, a phenomenon that can be attributed to the greater generation and higher mobility of $\mathrm{O}^{2-}$ in comparison to $\mathrm{OH}^{-}$under a high electric field. Furthermore, a higher anodization temperature caused more diffusion of $\mathrm{F}^{-}$, subsequently increasing the etching rate and the size of the synthesized NPs significantly. The anodization process, described in this work, is much simpler than the conventional procedures and can be used to quickly mass-produce $\mathrm{SiO}_{\mathrm{x}} \mathrm{NPs}$ by implementing a large number of Si electrodes.

Supplementary Materials: The following are available online at http://www.mdpi.com/2079-4991/10/11/2137/s1, Figure S1: FESEM images and their high contrast counterparts of $\mathrm{SiO}_{\mathrm{x}} \mathrm{NPs}$ synthesized at voltages of (a) $7.5 \mathrm{~V}$, (b) $10.0 \mathrm{~V}$, and (c) $12.5 \mathrm{~V}$ at a constant temperature of $5{ }^{\circ} \mathrm{C}$, Table $\mathrm{S} 1: \mathrm{Wt} \%$ of the elements in $\mathrm{SiO}_{\mathrm{x}} \mathrm{NPs}$ synthesized at voltages of (a) $7.5 \mathrm{~V}$, (b) $10.0 \mathrm{~V}$, and (c) $12.5 \mathrm{~V}$ at a constant temperature of $5^{\circ} \mathrm{C}$.

Author Contributions: Conceptualization and methodology, J.L. and S.O.C.; formal analysis and investigation, J.L., S.Y.L. and H.Y.J.; writing-original draft preparation, writing-review and editing, all authors. All authors have read and agreed to the published version of the manuscript.

Funding: This research was funded by a National Research Foundation of Korea (NRF) grant funded by the Korean government, grant numbers NRF-2019M2D2A1A02058174 and NRF-2020M2D8A2069727.

Conflicts of Interest: The authors declare no conflict of interest.

\section{References}

1. Jung, C.-O.; Park, D.-W. Synthesis of $\mathrm{SiO}_{\mathrm{x}}$ Powder Using DC Arc Plasma. J. Nanosci. Nanotechnol. 2013, 13, 1153-1158. [CrossRef] [PubMed]

2. Shin, D.H.; Choi, Y.S.; Ku, D.J.; Hong, Y.C.; Lee, B.J. Synthesis of $\mathrm{SiO}_{\mathrm{x}}$ Nano-Powders Using a Microwave Plasma Torch at Atmospheric Pressure. Soft Nanosci. Lett. 2016, 6, 31. [CrossRef]

3. Tomozeiu, N. Silicon oxide $\left(\mathrm{SiO}_{\mathrm{x}}, 0<\mathrm{x}<2\right)$ : A challenging material for optoelectronics. In OptoelectronicsMaterials and Techniques; Predeep, P., Ed.; InTech: Rijeka, Croatia, 2011; pp. 55-98.

4. Zarchi, M.; Ahangarani, S. Effect of Oxygen Concentration on the Structure and Optical Properties of $\mathrm{SiO}_{\mathrm{x}}$ Coatings. Surf. Eng. Appl. Electrochem. 2018, 54, 47-54. [CrossRef]

5. Nesheva, D. Photoluminescence from $\mathrm{SiO}_{x}$ layers containing amorphous silicon nanoparticles. Phys. Status Solidi A 2012, 209, 746-751. [CrossRef]

6. Klingsporn, M.; Kirner, S.; Villringer, C.; Abou-Ras, D.; Costina, I.; Lehmann, M.; Stannowski, B. Resolving the nanostructure of plasma-enhanced chemical vapor deposited nanocrystalline $\mathrm{SiO}_{\mathrm{x}}$ layers for application in solar cells. J. Appl. Phys. 2016, 119, 223104. [CrossRef]

7. Rahaman, O.; Mortazavi, B.; Rabczuk, T. A first-principles study on the effect of oxygen content on the structural and electronic properties of silicon suboxide as anode material for lithium ion batteries. J. Power Sources 2016, 307, 657-664. [CrossRef]

8. Liu, Z.; Yu, Q.; Zhao, Y.; He, R.; Xu, M.; Feng, S.; Li, S.; Zhou, L.; Mai, L. Silicon oxides: A promising family of anode materials for lithium-ion batteries. Chem. Soc. Rev. 2019, 48, 285-309. [CrossRef]

9. Jang, B.Y.; Lee, J.S.; Kim, J.S. $\mathrm{SiO}_{x}$ Nanoparticles Synthesized by an Evaporation and Condensation Process Using Induction Melting of Silicon and Gas Injection. J. Nanosci. Nanotechnol. 2013, 13, 3690-3695. [CrossRef]

10. Yang, J.; Takeda, Y.; Imanishi, N.; Capiglia, C.; Xie, J.Y.; Yamamoto, O. SiO ${ }_{\mathrm{x}}$-based anodes for secondary lithium batteries. Solid State Ion. 2002, 152, 125-129. [CrossRef]

11. Seong, I.W.; Yoon, W.Y. Electrochemical behavior of a silicon monoxide and Li-powder double layer anode cell. J. Power Sources 2010, 195, 6143-6147. [CrossRef]

12. Van Duy, N.; Jung, S.; Nga, N.T.; Son, D.N.; Cho, J.; Lee, S.; Lee, W.; Yi, J. The investigation of an amorphous $\mathrm{SiO}_{\mathrm{x}}$ system for charge storage applications in nonvolatile memory at low temperature process. Mater. Sci. Eng. B 2010, 175, 176-180. [CrossRef] 
13. Chou, C.-Y.; Hwang, G.S. Lithiation behavior of silicon-rich oxide $\left(\mathrm{SiO}_{1 / 3}\right)$ : A first-principles study. Chem. Mater. 2013, 25, 3435-3440. [CrossRef]

14. Sun, L.; Su, T.; Xu, L.; Liu, M.; Du, H.-B. Two-dimensional ultra-thin $\mathrm{SiO}_{\mathrm{x}}(0<\mathrm{x}<2)$ nanosheets with long-term cycling stability as lithium ion battery anodes. Chem. Commun. 2016, 52, 4341-4344.

15. Tie, X.; Han, Q.; Liang, C.; Li, B.; Zai, J.; Qian, X. Si@SiO $/$ /Graphene Nanosheets Composite: Ball Milling Synthesis and Enhanced Lithium Storage Performance. Front. Mater. 2018, 4, 47. [CrossRef]

16. Bräuer, G. Large area glass coating. Surf. Coat. Technol. 1999, 112, 358-365. [CrossRef]

17. Li, W.T.; Boswell, R.; Samoc, M.; Samoc, A.; Wang, R.P. The effect of defects on the optical nonlinearity of thermally poled $\mathrm{SiO}_{\mathrm{x}}$ thin films. Thin Solid Films 2008, 516, 5474-5477. [CrossRef]

18. Miyazaki, H. Refractive index and dielectric constant of $\mathrm{SiO}_{x}$ films deposited by reactive sputtering. Phys. Chem. Glasses Eur. J. Glass Sci. Technol. B 2010, 51, 136-137.

19. Zhang, S.; Yao, Y.; Hu, D.; Lian, W.; Qian, H.; Jie, J.; Wei, Q.; Ni, Z.; Zhang, X.; Xie, L. Application of silicon oxide on high efficiency monocrystalline silicon PERC solar cells. Energies 2019, 12, 1168. [CrossRef]

20. Han, S.; Grozea, D.; Huang, C.; Lu, Z.H.; Wood, R.; Kim, W.Y. Al:SiO thin films for organic light-emitting diodes. J. Appl. Phys. 2004, 96, 709-714. [CrossRef]

21. Mehonic, A.; Buckwell, M.; Montesi, L.; Munde, M.S.; Gao, D.; Hudziak, S.; Chater, R.J.; Fearn, S.; McPhail, D.; Bosman, M. Nanoscale Transformations in Metastable, Amorphous, Silicon-Rich Silica. Adv. Mater. 2016, 28, 7486-7493. [CrossRef]

22. Mehonic, A.; Shluger, A.L.; Gao, D.; Valov, I.; Miranda, E.; Ielmini, D.; Bricalli, A.; Ambrosi, E.; Li, C.; Yang, J.J. Silicon oxide $\left(\mathrm{SiO}_{\mathrm{x}}\right)$ : A promising material for resistance switching? Adv. Mater. 2018, 30, 1801187. [CrossRef] [PubMed]

23. Yuan, Z.; Bariya, M.; Fahad, H.M.; Wu, J.; Han, R.; Gupta, N.; Javey, A. Trace-Level, Multi-Gas Detection for Food Quality Assessment Based on Decorated Silicon Transistor Arrays. Adv. Mater. 2020, 32, 1908385. [CrossRef] [PubMed]

24. Tsigkourakos, M.; Bousoulas, P.; Aslanidis, V.; Skotadis, E.; Tsoukalas, D. Ultra-Low Power Multilevel Switching with Enhanced Uniformity in Forming Free $\mathrm{TiO}_{2-x}$-Based RRAM with Embedded Pt Nanocrystals. Phys. Status Solidi A 2017, 214, 1700570. [CrossRef]

25. Lai, Y.; Qiu, W.; Zeng, Z.; Cheng, S.; Yu, J.; Zheng, Q. Resistive switching of plasma-treated zinc oxide nanowires for resistive random access memory. Nanomaterials 2016, 6, 16. [CrossRef] [PubMed]

26. Kim, J.; Kim, B.; Oh, C.; Ryu, J.; Kim, H.; Park, E.; No, K.; Hong, S. Effects of $\mathrm{NH}_{4} \mathrm{~F}$ and distilled water on structure of pores in $\mathrm{TiO}_{2}$ nanotube arrays. Sci. Rep. 2018, 8, 1-8. [CrossRef]

27. Su, Z.; Zhou, W. Formation, morphology control and applications of anodic $\mathrm{TiO}_{2}$ nanotube arrays. J. Mater. Chem. 2011, 21, 8955-8970. [CrossRef]

28. Sulka, G.D. Highly ordered anodic porous alumina formation by self-organized anodizing. In Nanostructured Materials in Electrochemistry; Eftekhari, A., Ed.; Wiley-VCH Verlag GmbH \& Co. KGaA: Weinheim, Germany, 2008; Volume 1, pp. 1-116.

29. Park, Y.J.; Ha, J.M.; Ali, G.; Kim, H.J.; Addad, Y.; Cho, S.O. Controlled fabrication of nanoporous oxide layers on zircaloy by anodization. Nanoscale Res. Lett. 2015, 10, 377. [CrossRef]

30. Ali, G.; Park, Y.J.; Kim, J.W.; Cho, S.O. A Green, General, and Ultrafast Route for the Synthesis of Diverse Metal Oxide Nanoparticles with Controllable Sizes and Enhanced Catalytic Activity. ACS Appl. Nano Mater. 2018, 1, 6112-6122. [CrossRef]

31. Canham, L. Handbook of Porous Silicon, 1st ed.; Springer: Berlin, Germany, 2014.

32. Chazalviel, J.-N.; Ozanam, F. Electrochemically formed porous silica. Materials 2011, 4, 825-844. [CrossRef]

33. Schneider, C.A.; Rasband, W.S.; Eliceiri, K.W. NIH Image to ImageJ: 25 years of image analysis. Nat. Methods 2012, 9, 671-675. [CrossRef]

34. Moulder, J.F.; Stickle, W.F.; Sobol, P.E.; Bomben, K.D. Handbook of X-Ray Photoelectron Spectroscopy, 1st ed.; Chastain, J., Ed.; Perkin-Elmer Corp.: Eden Prairie, MN, USA, 1992.

35. Himpsel, F.j.; McFeely, F.R.; Taleb-Ibrahimi, A.; Yarmoff, J.A.; Hollinger, G. Microscopic structure of the $\mathrm{SiO}_{2} / \mathrm{Si}$ interface. Phys. Rev. B 1988, 38, 6084. [CrossRef] [PubMed]

36. Zhang, W.; Zhang, S.; Liu, Y.; Chen, T. Evolution of Si suboxides into Si nanocrystals during rapid thermal annealing as revealed by XPS and Raman studies. J. Cryst. Growth 2009, 311, 1296-1301. [CrossRef]

37. Barranco, A.; Mejías, J.A.; Espinós, J.P.; Caballero, A.; Gonzalez-Elipe, A.R.; Yubero, F. Chemical stability of $\mathrm{Si}^{\mathrm{n}+}$ species in $\mathrm{SiO}_{\mathbf{x}}(\mathrm{x}<2)$ thin films. J. Vac. Sci. Technol. A Vac. Surf. Films 2001, 19, 136-144. 
38. López, J.A.L.; Valerdi, D.E.V.; Lara, A.B.; Salgado, G.G.; Hernández-de la Luz, A.D.; Sánchez, A.M.; Gracia, F.J.F.; Dominguez, M.A. Optical and compositional properties of $\mathrm{SiO}_{\mathrm{x}}$ films deposited by HFCVD: Effect of the hydrogen flow. J. Electron. Mater. 2017, 46, 2309-2322. [CrossRef]

39. Roy, P.; Berger, S.; Schmuki, P. $\mathrm{TiO}_{2}$ nanotubes: Synthesis and applications. Angew. Chem. Int. Ed. 2011, 50, 2904-2939. [CrossRef] [PubMed]

40. Radtke, A.; Bal, M.; Jedrzejewski, T. Novel titania nanocoatings produced by anodic oxidation with the use of cyclically changing potential: Their photocatalytic activity and biocompatibility. Nanomaterials 2018, 8, 712. [CrossRef]

41. Sahrin, N.T.; Nawaz, R.; Kait, C.F.; Lee, S.L.; Wirzal, M.D.H. Visible Light Photodegradation of Formaldehyde over $\mathrm{TiO}_{2}$ Nanotubes Synthesized via Electrochemical Anodization of Titanium Foil. Nanomaterials 2020, 10, 128. [CrossRef]

42. Li, F.; Zhang, L.; Metzger, R.M. On the growth of highly ordered pores in anodized aluminum oxide. Chem. Mater. 1998, 10, 2470-2480. [CrossRef]

43. Yin, H.; Liu, H.; Shen, W.Z. The large diameter and fast growth of self-organized $\mathrm{TiO}_{2}$ nanotube arrays achieved via electrochemical anodization. Nanotechnology 2009, 21, 035601. [CrossRef]

Publisher's Note: MDPI stays neutral with regard to jurisdictional claims in published maps and institutional affiliations.

(C) 2020 by the authors. Licensee MDPI, Basel, Switzerland. This article is an open access article distributed under the terms and conditions of the Creative Commons Attribution (CC BY) license (http://creativecommons.org/licenses/by/4.0/). 